\title{
Too Low to Kill \\ Concentration of the Secondary Metabolite Ranunculin in Buttercup Pollen does not Affect Bee Larval Survival
}

\section{Journal Article}

Author(s):

Sedivy, Claudio; Piskorski, Rafal; Muller, Andreas; Dorn, Silvia

Publication date:

2012-08

Permanent link:

https://doi.org/10.3929/ethz-b-000057340

Rights / license:

In Copyright - Non-Commercial Use Permitted

Originally published in:

Journal of Chemical Ecology 38(8), https://doi.org/10.1007/s10886-012-0153-3 


\title{
Too Low to Kill: Concentration of the Secondary Metabolite Ranunculin in Buttercup Pollen does not Affect Bee Larval Survival
}

\author{
Claudio Sedivy • Rafal Piskorski • Andreas Müller • \\ Silvia Dorn
}

Received: 6 September 2011 /Revised: 19 April 2012 / Accepted: 3 June 2012 /Published online: 19 June 2012

(C) Springer Science+Business Media, LLC 2012

\begin{abstract}
Growing evidence suggests that the freely accessible pollen of some plants is chemically protected against pollen-feeding flower visitors. For example, a diet of pollen from buttercup plants (Ranunculus) recently was shown to have a deleterious effect on developing larvae of several bee species not specialized on Ranunculus. Numerous Ranunculus species contain ranunculin, the glucosyl hydrate form of the highly reactive and toxic lactone protoanemonin, that causes the toxicity of these plants. We tested whether the presence of ranunculin is responsible for the lethal effects of $R$. acris pollen on the larvae of two bee species that are not Ranunculus specialists. To investigate the effect on bee larval development, we added ranunculin to the pollen provisions of the Campanula specialist bee Chelostoma rapunculi and the Asteraceae specialist bee Heriades truncorum, and allowed the larvae to feed on these provisions. We quantified ranunculin in pollen of $R$. acris and in brood cell provisions collected by the Ranunculus specialist bee Chelostoma florisomne. We demonstrated that although ranunculin was lethal to both tested bee species in high concentrations, the concentration in the pollen of $R$. acris was at least fourfold lower than that tolerated by the larvae of $C$. rapunculi and $H$. truncorum in the feeding experiments. Ranunculin concentration in the brood cells of $C$.
\end{abstract}

C. Sedivy $\cdot$ R. Piskorski $\cdot$ A. Müller $(\bowtie) \cdot$ S. Dorn

ETH Zurich, Institute of Agricultural Sciences,

Applied Entomology,

Schmelzbergstrasse 9/LFO,

8092 Zurich, Switzerland

e-mail: andreas.mueller@ipw.agrl.ethz.ch

Present Address:

R. Piskorski

Innovative Environmental Services (IES) Ltd.,

Benkenstrasse 260,

4108 Witterswil, Switzerland florisomne was on average even twentyfold lower than that in Ranunculus pollen, suggesting that a mechanism different from ranunculin intoxication accounts for the larval mortality reported for bees not specialized on Ranunculus pollen.

Keywords Ranunculus $\cdot$ Ranunculin $\cdot$ Protoanemonin · Pollen · Plant defense · Osmiini · Chelostoma · Heriades . Megachilidae

\section{Introduction}

Bees, including solitary native species, provide important ecosystem services as pollinators of flowering plants (Kremen et al., 2007). However, they exact considerable costs on plants, because they require enormous quantities of pollen to feed their broods (Müller et al., 2006). Flowers are expected to balance the need to attract bees for pollination with the need to restrict extensive pollen losses (Praz et al., 2008a; Sedivy et al., 2011). Various mechanisms have evolved that limit pollen loss by narrowing the spectrum of pollen-collecting flower visitors (Westerkamp, 1997; Westerkamp and Classen-Bockhoff, 2007) or by reducing the pollen quantity withdrawn by pollinators per flower visit. Examples of these mechanisms include specialized anthers, pollen-concealing flower structures, and portioned pollen release over extended time periods (Vogel, 1993; Harder and Barclay, 1994; Müller, 1996; Castellanos et al., 2006).

Growing evidence suggests that some plants that possess freely accessible pollen might also chemically protect the pollen. For example, the pollen of Stryphnodendron polyphyllum (Mimosoideae) is poisonous to the larvae of the honeybee (De Carvalho and Message, 2004). Similarly, the pollen of Ranunculus (Ranunculaceae) did not support larval development of three strict pollen-specialist bees specialized on 
Campanula, Echium, and Asteraceae, respectively, as well as one highly pollen-generalist bee (Praz et al., 2008a; Sedivy et al., 2011). The larval mortality pattern in these four species was characterized by rapid death upon onset of feeding, suggesting that Ranunculus pollen may contain secondary metabolites that are toxic to bee larvae. Ranunculus pollen also is known to be toxic to adult honeybees, which suffer high rates of mortality when feeding primarily on Ranunculus pollen, a phenomenon known as "Bettlacher May sickness" (Morgenthaler and Maurizio, 1941).

Fresh plants of the genus Ranunculus are known for their toxic effect on livestock (Kingsbury, 1964). This effect arises from high concentrations of the glucoside ranunculin, the precursor of the toxic protoanemonin, present in the plant tissue (Fig. 1) (Benn and Yelland, 1968). The content of ranunculin in Ranunculus species normally oscillates around $10 \mathrm{mg}$ per g dry weight (d.w.) (Ruijgrok, 1966), but can reach nearly $200 \mathrm{mg} / \mathrm{g}$ d.w. in $R$. cymbalaria (Bai et al., 1996). Upon infliction of mechanical damage to plant tissue, the non-toxic ranunculin is hydrolyzed by endogenous $\beta$ glucosidase, an enzyme stored in the vacuole (Mauch and Staehelin, 1989), to yield the highly reactive anhydroaglycone protoanemonin (2,3-dihydro-5-methylidenefuran-2-one), a volatile lactone (Hill and Van Heyningen, 1951). When ingested, protoanemonin can cause gastric distress in livestock (Kingsbury, 1964). Applied to human skin, protoanemonin may produce erythema and blistering (Benn and Yelland, 1968). In addition, protoanemonin has antimicrobial properties (Campbell et al., 1979; Mares, 1987; Martin et al., 1990) and exhibits insecticidal effects on fly larvae of Drosophila melanogaster (Drosophildae), adult beetles of Tribolium castaneum (Tenebrionidae), and ant workers of Pheidole pallidula (Formicidae) (Bhattacharya et al., 1993; Varitimidis et al., 2006).

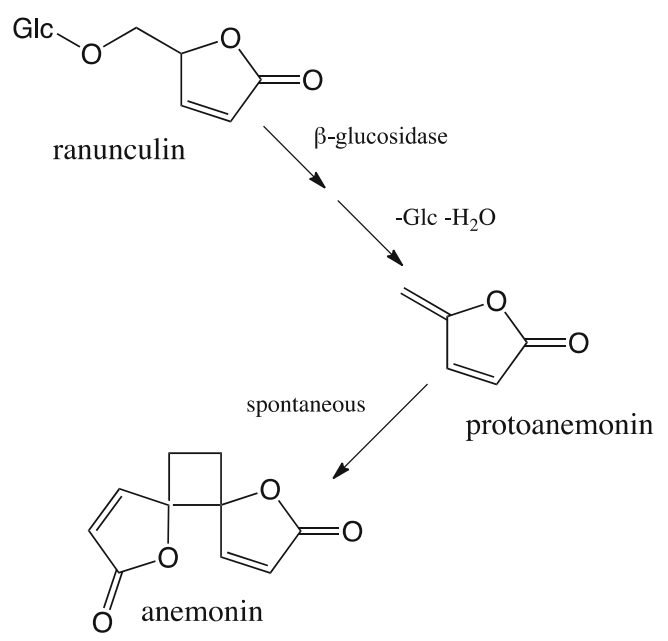

Fig. 1 The transformation of the glucoside ranunculin to the unstable and toxic lactone protoanemonin in plant tissue and spontaneous transformation to anemonin. Modified after Benn and Yelland (1968)
Some herbivorous insects are able to cope with high concentrations of ranunculin in their diet. Larvae of several leaf and stem mining species of agromyzid flies of the genus Phytomyza are specialized on Ranunculus and other ranunculin-containing genera of the Ranunculaceae, e.g., Anemone, Clematis, and Helleborus (Spencer, 1990). Larvae of $P$. ranunculi and $P$. ranunculivora often are found in leaves of $R$. acris (Pitkin et al., 2010), where they can be exposed to ranunculin concentrations of about $28 \mathrm{mg} / \mathrm{g}$ d.w. (Bai et al., 1996). The physiological basis of the ability of these herbivorous insects to tolerate ranunculin and/or protoanemonin remains unknown.

While stems, leaves, and the androecium of Ranunculus contain ranunculin in considerable amounts (Ruijgrok, 1966; Bonora et al., 1988; Bai et al., 1996), no attempt has been made to quantify ranunculin in Ranunculus pollen. The high relative amounts of protoanemonin released from pollen and anthers of some Ranunculus species (Bergström et al., 1995) as well as the high concentration of protoanemonin in the androeceum of $R$. ficaria, which was found to be twice as high as the concentration measured in the whole plant (Bonora et al., 1988), may indicate the presence of substantial quantities of ranunculin in the pollen of Ranunculus. Furthermore, by thermal desorption of anthers of several Ranunculaceae, Jürgens and Dötterl (2004) detected high relative amounts of protoanemonin in three Ranunculus species, and protoanemonin from Ranunculus pollen seems to be used in host-plant recognition by the Ranunculus specialist bee Chelostoma florisomne (Dobson and Peng, 1997).

We hypothesized that protoanemonin released from the secondary metabolite ranunculin is responsible for the toxicity of $R$. acris pollen to the larvae of bee species that are not Ranunculus specialists. To investigate the effect of ranunculin on larval development, we selected two solitary bee species specialized on pollen of plants other than $R a$ nunculus. We tested larval performance of Chelostoma rapunculi, a Campanula pollen specialist, and Heriades truncorum, an Asteraceae pollen specialist, on diets consisting of pollen from their natural host plants mixed with ranunculin in various concentrations. In addition, we quantified ranunculin in pollen and flower buds of $R$. acris as well as in brood cell provisions of Chelostoma florisomne, which is a pollen-specialist species that collects pollen exclusively from Ranunculus flowers (Sedivy et al., 2008).

\section{Material and Methods}

Bee Species To assess the effect of ranunculin on larval development of solitary bees, we selected two species belonging to the same taxonomic group (Osmiini; Megachilidae) as the Ranunculus specialist Chelostoma florisomne. These species, Chelostoma rapunculi and Heriades 
truncorum, are specialized on Campanula (Campanulaceae) and on Asteraceae, respectively (Westrich, 1989; Praz et al., 2008b; Sedivy et al., 2008). Neither can develop on a Ranunculus pollen diet (Praz et al., 2008a). All these species nest in pre-existing cavities such as insect-bored holes in dead wood and hollow stems, and they can easily be reared in hollow bamboo stalks. Once provisioning of the brood cells with pollen and nectar is complete, an egg is deposited onto the pollen diet, and the female bee closes the cell with a thin wall of clay or resin. Successful larval development ends with spinning a cocoon, in which the bee enters metamorphosis to the adult stage. For the experiments, we used eggs and brood cell provisions from bees in nesting stands on the campus of ETH Zurich.

Bee Larval Performance The larvae of C. rapunculi and $H$. truncorum were experimentally reared on a Campanula and Asteraceae pollen diet, respectively, obtained from conspecific nests and mixed with ranunculin in five increasing concentrations: 0 (control), 10, 20, 50, and $100 \mathrm{mg}$ per $\mathrm{g}$ pollen dry weight (d.w.), henceforth referred to as the control treatment, 10, 20,50, and $100 \mathrm{mg} / \mathrm{g}$ treatment. These concentrations are in line with natural ranunculin concentrations reported for Ranunculus plants (Ruijgrok, 1966; Bonora et al., 1988; Bai et al., 1996). Pollen dry weight of the brood cell provisions averages approximately $27 \%$ in $C$. rapunculi and $33 \%$ in H. truncorum (A. Bühler and A. Müller, unpublished). Ranunculin ( $>99 \%$ pure) originating from extractions of Ranunculus plants was obtained from Michael H. Benn (University of Calgary, Canada). To prepare the experimental pollen diet, ranunculin was ground to fine powder and thoroughly mixed with the brood cell provisions in a mortar. The mixing process was conducted in a careful and gentle way to prevent destruction of the pollen grains and, thus, to prevent the release of $\beta$ glucosidase followed by hydrolysis of ranunculin.

Rearing of bee larvae was conducted in individual artificial brood cells (for details see Sedivy et al., 2011). Freshly completed bee nests were collected daily from the nesting stands. Each egg was detached with a thin spatula from the brood cell provision and transferred onto $60 \mathrm{mg}$ of the experimental pollen diet previously placed into the artificial cell. Larvae hatched and started feeding between 1 and $3 \mathrm{~d}$ after transfer onto the experimental pollen diet. Each larva was allowed to feed individually in a single artificial cell to mimic natural conditions. For each species and treatment, 24-31 eggs were transferred. Development took place in a climate chamber (E7 / 2; Conviron, Winnipeg, Canada) in darkness at $25 \pm 0.5{ }^{\circ} \mathrm{C}$ for $16 \mathrm{~h}$ followed by a $4 \mathrm{~h}$ gradual decrease to $10 \pm 0.5^{\circ} \mathrm{C}$, followed by a $4 \mathrm{~h}$ gradual increase back to $25 \pm 0.5^{\circ} \mathrm{C}$, at a constant $70 \pm 0.5 \%$ relative humidity. Egg hatching, initiation of larval feeding, cocoon completion, and incidences of death were recorded every second day. Survival time was considered the time between onset of feeding and either death or completion of the cocoon. Unhatched eggs were removed from statistical analyses.

Statistical Analysis Kaplan-Meier survival statistics was used to compare larval survival among the different treatments following Lee and Wang (2003). The number of days between hatching and completion of the cocoon was considered as 'censored data'; individuals that died before the completion of the cocoon represented the exact observations for which the event (death) occurred, while those that completed the cocoon were the censored observations. The latter were considered survivors and were withdrawn from survival calculations. To test for differences among survival distributions, the log-rank test was applied with Bonferroni correction using the option 'pairwise for each stratum' implemented in the software when comparing two groups. For each species, we tested for differences in survival according to pollen-diet treatment, and larval survival of the two species was compared for each ranunculin concentration. For statistical analyses, SPSS 19.0.0 for Macintosh OS X (SPSS Inc., Chicago, IL, USA) was used.

Ranunculin Recovery To test whether the ranunculin concentration in the experimental pollen provisions remained stable during feeding experiments, we added $10 \mathrm{mg} / \mathrm{g}$ of ranunculin to brood cell provisions of Heriades truncorum and quantified the ranunculin content by LC-MS analysis (see below) immediately after mixing, after $8 \mathrm{~d}$ and after $22 \mathrm{~d}$ ( $N=5$ for each time interval). For this experiment, we used the same methodological procedure including climate chamber conditions as for the bee larval performance experiments.

Plant Material Ranunculin was quantified in pollen and flower buds of Ranunculus acris as well as in the brood cell provisions of the Ranunculus specialist Chelostoma florisomne. At each of 8 different locations in Switzerland, which spanned a geographic range of approximately $130 \mathrm{~km}$ (comprising locations around Neuchâtel, Solothurn, Aarau, and Zurich), 250 freshly opened flowers of $R$. acris were collected in April 2011. Flowers were bundled and fixed in an upside-down position over a parchment paper cone large enough to collect released pollen. After $24 \mathrm{~h}$, the pollen that accumulated at the bottom of the cone was sieved through a $90 \mu \mathrm{m}$-pore sieve and stored at $-80^{\circ} \mathrm{C}$ until extraction and analysis. Our pollen collection procedure closely matched the pollen collecting behavior of bees, which harvest pollen from dehisced anthers before they deposit it in the brood cells. At each of the 8 locations, a single flower bud (close to blooming) was collected from each of 5 different plants, was immediately frozen in liquid nitrogen, and stored at $-80^{\circ} \mathrm{C}$ until extraction and analysis. 
At a large nesting site of $C$. florisomne in the surroundings of Neuchâtel (Gletterens), where R. acris was the near exclusive pollen source for this species, we collected 11 freshly completed nests. From each nest, the provision of the outermost (i.e., the most recently completed) brood cell was removed and immediately stored at $-80^{\circ} \mathrm{C}$ until extraction and analysis.

Extractions of Plant Material For extraction of ranunculin we basically followed the method described by Bai et al. (1996). All samples, i.e., pollen, flower buds, and brood cell provisions, were freeze-dried and individually extracted with methanol $(3 \times 15 \mathrm{ml})$ by repeatedly and thoroughly grinding in a mortar. To ensure that the mechanical damage inflicted on the plant material did not lead to a significant loss of ranunculin due to the action of $\beta$-glucosidase, the grinding was conducted in methanol. To test whether the hard pollen exine was successfully disrupted in order to extract the complete contents of the pollen grains, the ground pollen was examined microscopically. Extracts were filtered through a cotton plug, evaporated to dryness, and stored at $-60^{\circ} \mathrm{C}$ until LC-MS analysis.

LC-MS Analysis For the LC-MS analysis, the total dried extract was quantitatively dissolved in the mobile phase, and if necessary, an aliquot of the solution was further diluted. High-performance liquid chromatography (HPLC) was performed on an Agilent 1200 HPLC system (Agilent Ltd., Santa Clara, CA, USA) equipped with a binary solvent pump. Separation was performed on a reversed-phase 4.6$\mathrm{mm} \times 250-\mathrm{mm}, 5 \mu \mathrm{m}$, Phenomenex ODS Aqua column (Phenomenex, Torrance, CA, USA). An isocratic mode with $\mathrm{MeOH} / \mathrm{H}_{2} \mathrm{O}(0.05 \%$ ammonium acetate) (6:4) at a flow rate of $1 \mathrm{ml} / \mathrm{min}$ (total run time, $5 \mathrm{~min}$ ) was employed. The sample injection volume was $5 \mu \mathrm{l}$.

Mass spectrometry (MS) was performed on an electrospray ionization-quadrupole-time of flight (ESI-Q-TOF) MS system (maXis, Bruker Daltonics, Bexhill-on-Sea, UK). The instrument was operated in a wide-pass quadrupole mode, and the TOF data was collected for $m / z$ 50-1300 with lowcollision energy of $8 \mathrm{eV}$. The optimized ion source and mass analyzer conditions were as follows: drying gas, $\mathrm{N}_{2}$ $(99.99 \%)$ at $8.0 \mathrm{l} / \mathrm{h}$ and temperature of $200{ }^{\circ} \mathrm{C}$; nebulizer pressure 1.6 bar; capillary and endplate voltages $500 \mathrm{~V}$ and $4,500 \mathrm{~V}$, respectively; TOF tube voltage $9,880 \mathrm{~V}$; reflection voltage 2,004 V; pusher voltage 1,640 V; MCP detector voltage $2,927 \mathrm{~V}$. The system was mass calibrated in the positive-ion mode using a methanol solution of sodium formate on the enhanced quadratic algorithmic mode.

The signal of the extracted ion chromatogram at $\mathrm{m} / \mathrm{z}$ $299.1\left([\mathrm{M}+\mathrm{Na}]^{+}\right)$was employed for the quantification of ranunculin as sodium adduct. Quantification was performed using a five-point calibration curve obtained with pure ranunculin using the Data Analysis 4.0 and Quant Analysis 2.0 software (Bruker Daltonics, Bexhill-on-Sea, UK).

\section{Results}

Bee Larval Performance All larvae of Chelostoma rapunculi died within 4-10 d (median, $6 \mathrm{~d}$ ) when feeding on the $50 \mathrm{mg} / \mathrm{g}$ and the $100 \mathrm{mg} / \mathrm{g}$ ranunculin treatment (Fig. 2a), while $29 \%$ of the larvae survived on the $20 \mathrm{mg} / \mathrm{g}$ treatment (Table 1). Larval survival did not differ significantly between the control and the $10 \mathrm{mg} / \mathrm{g}$ and $20 \mathrm{mg} / \mathrm{g}$ treatments, respectively (log-rank test, $\chi^{2}=5.688, P=0.17$ and $\chi^{2}=$ 3.682, $P=0.55$ after Bonferroni correction), but differed significantly between the $10 \mathrm{mg} / \mathrm{g}$ and the $20 \mathrm{mg} / \mathrm{g}$ treatment $\left(\log\right.$-rank test, $\left.\chi^{2}=17.998, P<0.001\right)$. The larvae feeding on the control treatment required 20-34 d (median, $28 \mathrm{~d}$ ) until completion of the cocoons compared to $34-56 \mathrm{~d}$ (median, $42 \mathrm{~d}$ ) on the $10 \mathrm{mg} / \mathrm{g}$ treatment and 32-50 d (median, $44 \mathrm{~d}$ ) on the $20 \mathrm{mg} / \mathrm{g}$ treatment.
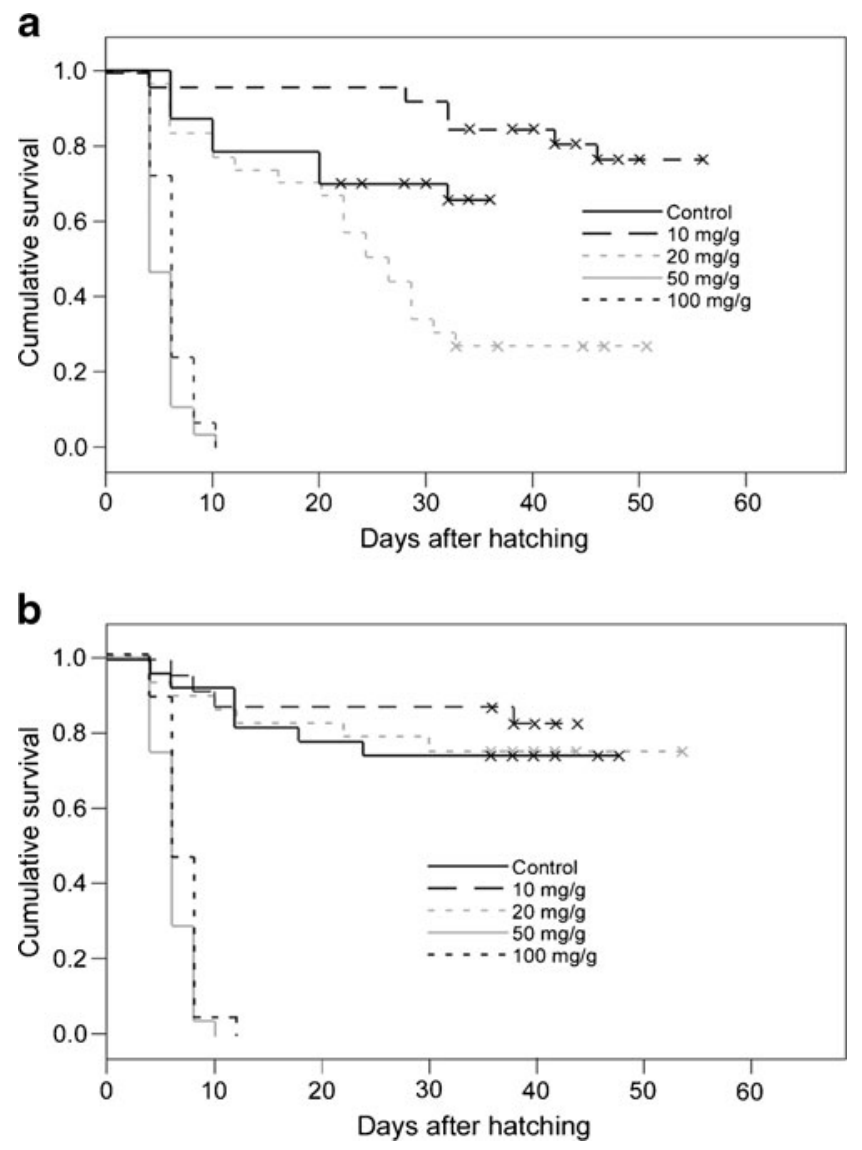

Fig. 2 Cumulative survival of larvae of bees specialized on plants other than Ranunculus when reared on their host pollen diet admixed with different quantities of ranunculin. Crosses indicate the days after hatching at which at least one individual reached the cocoon stage (censored data). a the Campanula specialist Chelostoma rapunculi, and $\mathbf{b}$ the Asteraceae specialist Heriades truncorum 
Table 1 Larval survival of the two bee species Chelostoma rapunculi and Heriades truncorum when reared on their host pollen diet mixed with ranunculin

a Survival time gives the Kaplan-Meier survival time in days (mean $\pm \mathrm{SEM}$ ) of the larvae on each pollen diet. Group heterogeneity was tested with the pairwise log-rank test between all treatments. Diets sharing the same letter did not differ significantly at $P<0.05$ (post hoc test: pairwise log-rank test using Bonferroni corrections)

\begin{tabular}{|c|c|c|c|c|c|c|c|}
\hline \multirow[t]{2}{*}{ Bee species } & \multirow{2}{*}{$\begin{array}{l}\text { Ranunculin } \\
\text { concentration } \\
\text { (mg/g d.w.) }\end{array}$} & \multirow{2}{*}{$\begin{array}{l}\text { Hatched eggs } \\
\text { (unhatched) } \\
N\end{array}$} & \multicolumn{3}{|c|}{ Surviving larvae } & \multicolumn{2}{|c|}{$\begin{array}{l}\text { Group } \\
\text { heterogeneity }\end{array}$} \\
\hline & & & $N$ & $\%$ & $\begin{array}{l}\text { Survival time } \\
\text { (days) }^{\mathrm{a}}\end{array}$ & $P$ & Groups \\
\hline \multirow[t]{5}{*}{ C. rapunculi } & 0 (control) & $23(1)$ & 15 & 65.2 & $26.30 \pm 2.35$ & \multirow[t]{5}{*}{$<0.001$} & $\mathrm{a}, \mathrm{b}$ \\
\hline & 10 & $28(2)$ & 22 & 78.6 & $49.17 \pm 2.59$ & & $\mathrm{a}$ \\
\hline & 20 & $31(0)$ & 9 & 29.0 & $26.71 \pm 2.99$ & & $\mathrm{~b}$ \\
\hline & 50 & $28(2)$ & 0 & 0 & $5.21 \pm 0.30$ & & $\mathrm{c}$ \\
\hline & 100 & $30(1)$ & 0 & 0 & $6.07 \pm 0.32$ & & $\mathrm{c}$ \\
\hline \multirow[t]{5}{*}{ H. truncorum } & 0 (control) & $29(1)$ & 23 & 79.3 & $35.52 \pm 2.39$ & \multirow[t]{5}{*}{$<0.001$} & $\mathrm{a}$ \\
\hline & 10 & $25(5)$ & 21 & 84.0 & $39.37 \pm 2.34$ & & $\mathrm{a}$ \\
\hline & 20 & $29(1)$ & 22 & 75.9 & $43.93 \pm 3.43$ & & $\mathrm{a}$ \\
\hline & 50 & $24(6)$ & 0 & 0 & $6.17 \pm 0.34$ & & $\mathrm{~b}$ \\
\hline & 100 & $28(2)$ & 0 & 0 & $6.86 \pm 0.32$ & & $\mathrm{~b}$ \\
\hline
\end{tabular}

All larvae of Heriades truncorum died within 4-12 d (median, $6 \mathrm{~d}$ ) when feeding on the $50 \mathrm{mg} / \mathrm{g}$ and $100 \mathrm{mg} / \mathrm{g}$ ranunculin treatment (Fig. 2b). Larval survival neither differed significantly between the control and the $10 \mathrm{mg} / \mathrm{g}$ and $20 \mathrm{mg} / \mathrm{g}$ treatments, respectively (log-rank test, $\chi^{2}=0.294, P=0.59$ and $\chi^{2}=0.118$, $P=0.73$ after Bonferroni correction), nor between the $10 \mathrm{mg} / \mathrm{g}$ and $20 \mathrm{mg} / \mathrm{g}$ treatment (log-rank test, $\chi^{2}=0.549, P=0.459$; Table 1). Larvae feeding on the control treatment required 30 $42 \mathrm{~d}$ (median, $34 \mathrm{~d}$ ) until completion of the cocoons compared to $36-44 \mathrm{~d}$ (median, $38 \mathrm{~d}$ ) on the $10 \mathrm{mg} / \mathrm{g}$ treatment and $36-54 \mathrm{~d}$ (median, $42 \mathrm{~d}$ ) on the $20 \mathrm{mg} / \mathrm{g}$ treatment.

A comparison between the two bee species tested revealed largely parallel performances across treatments; no significant differences were observed between the survival of the two species in the control, the $10 \mathrm{mg} / \mathrm{g}$, the $50 \mathrm{mg} / \mathrm{g}$, or the $100 \mathrm{mg} / \mathrm{g}$ treatments (log-rank test, $\chi^{2}=$ $1.48, P=0.224 ; \chi^{2}=0.995, P=0895 ; \chi^{2}=3.833, P=0.050$; $\left.\chi^{2}=3.032, P=0.082\right)$. In the $20 \mathrm{mg} / \mathrm{g}$ treatment, survival of $H$. truncorum larvae was greater than that of $C$. rapunculi larvae (log-rank test, $\left.\chi^{2}=11.347, P<0.001\right)$.

Ranunculin Recovery Recovery rate of ranunculin amounted to $62.5-71.0 \%$ (mean, $66.0 \%, N=5$ ) immediately after its addition to the experimental pollen provision, to $55.4-$ $70.5 \%$ (mean, $60.8 \%, N=5$ ) after $8 \mathrm{~d}$, and to $56.5-72.5 \%$ (mean, $63.2 \%, N=5$ ) after $22 \mathrm{~d}$. These results indicate that the concentration of ranunculin mixed to the pollen provisions remained constant over a substantial period of time, and that about $60 \%$ of the added $10 \mathrm{mg} / \mathrm{g}$ ranunculin was biologically available.

Ranunculin Content To quantify the range of ranunculin in the field-collected samples, we assessed its concentration in pollen, flower buds, and brood cells (Table 2). Ranunculin concentration in the pollen of Ranunculus acris (mean,
$0.55 \mathrm{mg} / \mathrm{g}$ ) was almost forty times lower than that in the flower buds (mean, $19.45 \mathrm{mg} / \mathrm{g}$ ), but almost twenty times greater than that in the brood cell provisions of Chelostoma florisomne (mean, $0.03 \mathrm{mg} / \mathrm{g}$ ). The maximum concentration of ranunculin found in the pollen of $R$. acris was $1.34 \mathrm{mg} / \mathrm{g}$ (Table 2). Neither protoanemonin, the ranunculin anhydroaglycone, nor anemonin, the product of spontaneous dimerization of protoanemonin, were detected in any of the samples.

\section{Discussion}

Results of the feeding experiments provide evidence that the two tested solitary bee species not specialized on Ranunculus tolerated the $10 \mathrm{mg} / \mathrm{g}$ ranunculin treatment without any measurable effects on larval survival. Based on the ranunculin recovery experiment, the $10 \mathrm{mg} / \mathrm{g}$ ranunculin treatment corresponds to an approximate concentration of biologically available ranunculin of at least $5.54 \mathrm{mg} / \mathrm{g} \mathrm{d} . \mathrm{w}$.

Table 2 Content of ranunculin quantified by LC-MS in pollen and flower buds of Ranunculus acris and in brood cell provisions of the Ranunculus specialist bee Chelostoma florisomne

\begin{tabular}{llll}
\hline Source & $N$ & Mean \pm SEM $[\mathrm{mg} / \mathrm{g}]$ & Range $[\mathrm{mg} / \mathrm{g}]$ \\
\hline Pollen & 8 & $0.55 \pm 0.18$ & $0.03-1.34$ \\
Flower buds & 8 & $19.45 \pm 5.20$ & $3.72-53.93$ \\
Brood cell provisions $^{\mathrm{a}}$ & 11 & $0.03 \pm 0.01$ & $0.003-0.12$ \\
\hline
\end{tabular}

${ }^{a}$ The Ranunculus pollen in the brood cell provisions was collected by foraging $C$. florisomne females from $R$. acris, which was the nearly exclusive pollen source for this species at the location where the brood cells were collected. Ranunculin amounts were calculated for pollen dry weight by subtracting average water and nectar contents in the brood cells 
However, ranunculin in the pollen of $R$. acris quantified by LC-MS analysis amounted to maximally $1.34 \mathrm{mg} / \mathrm{g}$ d.w., a concentration that is at least fourfold lower than that tolerated by Chelostoma rapunculi and Heriades truncorum. The maximum ranunculin concentration in the brood cell provisions of the Ranunculus specialist Chelostoma florisomne was one order of magnitude lower $(0.12 \mathrm{mg} / \mathrm{g}$ d.w. $)$ than in the freshly collected pollen of $R$. acris, although the pollen in the analyzed brood cell provisions was derived from this Ranunculus species. Ranunculin is lethal when added to the natural pollen provisions of $C$. rapunculi and H. truncorum at very high concentrations $(50 \mathrm{mg} / \mathrm{g}$ and $100 \mathrm{mg} / \mathrm{g}$ treatments). However, these concentrations greatly exceed natural concentrations of ranunculin found in $R$. acris pollen. Hence, the presence of ranunculin cannot explain the mortality of these bees when reared on a Ranunculus pollen diet, contrary to hypotheses proposed previously (Praz et al., 2008a; Sedivy et al., 2011).

Survival of $C$. rapunculi larvae feeding on the still high $10 \mathrm{mg} / \mathrm{g}$ and $20 \mathrm{mg} / \mathrm{g}$ ranunculin treatments was not significantly affected compared to the control treatment. However, mean survival values at the $20 \mathrm{mg} / \mathrm{g}$ treatment were low, and difference to the survival at the $10 \mathrm{mg} / \mathrm{g}$ treatment was significant, pointing to some adverse effects of the $20 \mathrm{mg} / \mathrm{g}$ treatment on larval survival. A sublethal effect (Piskorski et al., 2011a) of both the $20 \mathrm{mg} / \mathrm{g}$ and $10 \mathrm{mg} / \mathrm{g}$ treatments on $C$. rapunculi was noted as development times of the larvae were prolonged compared to the larvae in the control treatment.

Ranunculin admixed to the pollen provision at $10 \mathrm{mg} / \mathrm{g}$ could be recovered at a range of approximately $60 \%$, irrespective of whether the incubation period lasted 0,8 , or $22 \mathrm{~d}$. This finding indicates that a minor proportion of the ranunculin was deactivated during mixing, either through an adsorption or a chemical degradation. This result further indicates that the biologically available ranunculin concentration remained constant over long periods after mixing, thus underlining the validity of the conclusions drawn here.

Two previous studies described protoanemonin, the compound derived from hydrolysis of ranunculin, as the most prominent volatile in the headspace of pollen samples of $R$. acris (Bergström et al., 1995) and after thermal desorption of anthers of $R$. acris and other Ranunculaceae species (Jürgens and Dötterl, 2004). In both cases, only relative amounts were provided, and no information was given regarding absolute quantities of this lactone present in a volatile profile poor in other compounds. In another study, in which protoanemonin in different organs of $R$. ficaria was quantified after steam distillation, the androeceum was found to emit almost twice as much protoanemonin as the whole plant (Bonora et al., 1988). In that study, however, ranunculin was not quantified in the pollen itself. Thus, the high amounts of protoanemonin measured in the headspace of the androeceum of $R$. ficaria might have been derived from a high concentration of ranunculin in the anther filaments, or in the anther tissue surrounding the pollen sacs prior to pollen release, rather than directly from the pollen. The low concentrations of ranunculin found in the pollen of R. acris in the current study is in line with the trace amounts of protoanemonin recently reported from an analysis of pollen volatiles of $R$. bulbosus (Piskorski et al. 2011b). The ranunculin concentrations we measured in the flower buds of $R$. acris, amounting to up to $54 \mathrm{mg} / \mathrm{g}$ d.w., corresponds to published levels of ranunculin in other ranunculincontaining Ranunculaceae species (Ruijgrok, 1966; Bai et al., 1996), thus validating our extraction and quantification methods.

Surprisingly, we found that the level of ranunculin in the pollen provision collected by $C$. florisomne was on average twentyfold lower than in pure pollen. Pollen in the cell provisions is diluted with nectar admixed by the foraging females at a ratio of approximately 1:1 (based on dry weight; A. Bühler and A. Müller, unpublished), explaining some but not all of the discrepancy noted between ranunculin concentrations in the flower pollen and in the bees' brood cell provisions. One process that substantially reduces ranunculin content in cut Ranunculus plants is drying, which triggers $\beta$-glucosidase-mediated autolysis of ranunculin with release of protoanemonin, yielding hay that is non-toxic to livestock (Majak, 2001). A similar process can likely be ruled out in the pollen harvested by C. florisomne, since the pollen is neither dried nor mechanically damaged during pollen collection, deposition, and storage in the brood cell. We hypothesize that the high sugar concentration originating from the nectar surrounding the pollen grains in the brood cell provisions may lead to an osmotic stress that provokes the release of protoanemonin from its precursor ranunculin, similar to the situation in drying Ranunculus plants.

In summary, the pollen of $R$. acris contains the secondary metabolite ranunculin in concentrations considerably below the lethal threshold for the tested bee larvae. Thus, we found no evidence that the incapability of several bee species to develop on a Ranunculus pollen diet is caused by ranunculin (Praz et al., 2008a; Sedivy et al., 2011). Hence, a different mechanism likely causes larval mortality of bees not specialized on Ranunculus pollen, such as the presence of another still unknown toxic pollen compound or the lack of essential nutrients in the pollen, e.g. certain sterols or amino acids.

Acknowledgments We thank Michael H. Benn (University of Calgary, Canada) for the gift of a substantial sample of ranunculin; Renato Zenobi and Louis Bertschi (MS service of the Laboratory of Organic Chemistry, ETH Zurich) for support and chemical analyses; the staff of the Neolithic village of Gletterens for providing bee nests; Bettina Gutbrodt and Mare Haider for technical support, and Heather Kirk and three anonymous reviewers for useful comments on the manuscript. 


\section{References}

BaI, Y., BenN, M. H., MAJAK, W., and McDiarmid, R. 1996. Extraction and HPLC determination of ranunculin in species of the buttercup family. J. Agr. Food Chem. 44:2235-2238.

BenN, M. H. and Yelland, L. J. 1968. Ranunculin. Can. J. Chem. 46:729-732.

BergströM, G., DobSON, H. E. M., and GRoth, I. 1995. Spatial fragrance patterns within the flowers of Ranunculus acris (Ranunculaceae). Plant. Syst. Evol. 195:221-242.

Bhattacharya, P. R., NATH, S. C., and Bordoloi, D. N. 1993. Insecticidal activity of Ranunculus sceleratus (L.) against Drosophila melanogaster and Tribolium castaneum. Indian J. Exp. Biol. 31:85-86.

Bonora, A., Botta, B., MEnZiani-Andreoli, E., and BrUni, A. 1988. Organ-specific distribution and accumulation of protoanemonin in Ranunculus ficaria L. Biochem. Physiol. Pfl. 183:443447.

Campbell, W. E., Cragg, G. M. L., and Powrie, A. H. 1979. Anemonin, protoanemonin and ranunculin from Knowltonia capensis. Phytochemistry 18:323-324.

Castellanos, M. C., Wilson, P., Keller, S. J., Wolfe, A. D., and Thomson, J. D. 2006. Anther evolution: pollen presentation strategies when pollinators differ. Am. Nat. 167:288-296.

De Carvalho, A. C. P. and Message, D. 2004. A scientific note on the toxic pollen of Stryphnodendron polyphyllum (Fabaceae, Mimosoideae) which causes sacbrood-like symptoms. Apidologie 35:89-90.

DOBSON, H. E. M. and PENG, Y. S. 1997. Digestion of pollen components by larvae of the flower-specialist bee Chelostoma florisomne (Hymenoptera: Megachilidae). J. Insect Physiol. 43:89100.

HARDER, L. D. and BARCLAY, R. M. R. 1994. The functional significance of poricidal anthers and buzz pollination: controlled pollen removal from Dodecatheon. Funct. Ecol. 8:509-517.

HILL, R. and VAN HEYNINGEN, R. 1951. Ranunculin: the precursor of the vesicant substance of the buttercup. Biochem. J. 49:332-335.

JÜRGENS, A. and DöTTERL, S. 2004. Chemical composition of anther volatiles in Ranunculaceae: genera-specific profiles in Anemone, Aquilegia, Caltha, Pulsatilla, Ranunculus, and Trollius species. Am. J. Bot. 91:1969-1980.

KingsBury, J. M. 1964. Poisonous Plants of the United States and Canada. Prentice-Hall, Englewood Cliffs, NJ.

Kremen, C., Williams, N. M., Aizen, M. A., Gemmill-Herren, B., Lebuhn, G., Minckley, R., PACKer, L., Potts, C. G., ROULSTON, T., STEFFAN-DEWENTER, I., VAZQUEZ, P., WINFREE, R., Adams, L., Crone, E. E., Greenleaf, S. S., KeItT, T. H., KleIN, A., REGETZ, J., and RicKeTts, T. H. 2007. Pollination and other ecosystem services produced by mobile organisms: a conceptual framework for the effects of land-use change. Ecol. Let. 10:299-314.

LEE, E. T. and WANG, J. W. 2003. Statistical Methods for Survival Data Analysis. Wiley and Sons, New York, NY.

MAJAK, W. 2001. Review of toxic glycosides in rangeland and pasture forages. J Range Manage 54:494-498.

MARES, D. 1987. Antimicrobial activity of protoanemonin, a lactone from ranunculaceous plants. Mycopathologia 98:133-140.
Martin, M. L., Roman, L. S., and DomingueZ, A. 1990. In vitro activity of protoanemonin, an antifungal agent. Planta Med. 56:66-69.

MAUCH, F. and StaEhelin, L. A. 1989. Functional implications of the subcellular localization of ethylene-induced chitinase and $\beta-1,3-$ glucanase in bean leaves. Plant Cell 1:447-457.

Morgenthaler, O. and Maurizio, A. 1941. Die "Bettlacher Maikrankheit", eine Vergiftung durch Hahnenfuss-Pollen. Schweizerische Bienenzeitung 1:447-457.

MÜlLER, A. 1996. Host-plant specialization in western palearctic anthidiine bees (Hymenoptera: Apoidea: Megachilidae). Ecol. Monogr. 66:235-257.

MÜLler, A., DiEner, S., SChNYdER, S., StUtZ, K., SEDIVy, C., and DORN, S. 2006. Quantitative pollen requirements of solitary bees: Implications for bee conservation and the evolution of bee-flower relationships. Biol. Conserv. 130:604-615.

PISKORSKI, R., INEICHEN, S., and DORN, S. 2011a. Ability of the oriental fruit moth Grapholita molesta (Lepidoptera: Tortricidae) to detoxify juglone, the main secondary metabolite in the nonhost plant walnut. J. Chem. Ecol. 37:1110-1116.

PISKORSKI, R., KRODER, S., and DORN, S. 2011b. Can pollen headspace volatiles and pollenkitt lipids serve as reliable chemical cues for bee pollinators? Chem. Biodivers. 8:577-586.

PITKIN, B., Ellis, W., Plant, C., and EDMunds, R. 2010. The leaf and stem mines of British flies and other insects. 〈http://www. ukflymines.co.uk>.

PRAZ, C. J., MÜLLER, A., and DORN, S. 2008a. Specialized bees fail to develop on non-host pollen: do plants chemically protect their pollen? Ecology 89:795-804.

PRAZ, C. J., MÜLlER, A., and DORN, S. 2008b. Host recognition in a pollen-specialist bee: evidence for a genetic basis. Apidologie 39:547-557.

RUIJGROK, H. W. L. 1966. The distribution of ranunculin and cyanogenetic compounds in the Ranunculaceae. Meeting of the Phytochemical Group. Comparative Phytochemistry, Cambridge UK, 1965:175-186.

Sedivy, C., PraZ, C. J., MÜller, A., Widmer, A., and Dorn, S. 2008. Patterns of host-plant choice in bees of the genus Chelostoma: the constraint hypothesis of host-range evolution in bees. Evolution 62:2487-2507.

SEDIVY, C., MÜLlER, A., and DoRn, S. 2011. Closely related pollen generalist bees differ in their ability to develop on the same pollen diet: evidence for physiological adaptations to digest pollen. Funct. Ecol. 25:718-725.

SPENCER, K. A. 1990. Host Specialization in the World Agromyzidae (Diptera). Kluwer Academic Publishers, Dordrecht, Netherlands.

VARITIMIDIS, C., PETRAKIS, P. V., VAGIAS, C., and RousSis, V. 2006. Secondary metabolites and insecticidal activity of Anemone pavonina. J. Biosciences 61:521-526.

Vogel, S. 1993. Betrug bei Pflanzen: Die Täuschblumen. Abhandlungen der Akademie der Wissenschaften und der Literatur in Mainz 1:5-48.

WESTERKAMP, C. 1997. Keel blossoms: bee flowers with adaptations against bees. Flora 192:125-132.

WeSTERKAMP, C. and ClASSEN-BOCKHOFF, R. 2007. Bilabiate flowers: the ultimate response to bees? Ann. Bot. 100:361-374.

Westrich, P. 1989. Die Wildbienen Baden-Württembergs. Ulmer, Stuttgart, Germany. 